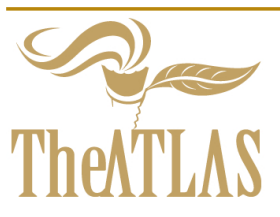

\title{
Research In-between: The Constitutive Role of Cultural Differences in Transdisciplinarity
}

Ulli Vilsmaier ${ }^{1}$, Vera Brandner ${ }^{2}$, Moritz Engbers ${ }^{3},{ }^{1}$ Leuphana University of Lüneburg, Methodology Center and Institute for Ethics and Transdisciplinary Sustainability Research, Email:vilsmaier@leuphana.de, ${ }^{2}$ University of Innsbruck, Department of Sociology, Email:vera.brandner@uibk.ac.at; ${ }^{3}$ Leuphana University of Lüneburg, Faculty of Sustainability and Methodology Center, Email:moritz.engbers@leuphana.de

Received 5 December, 2017; 22 December, 2017; 25 December 2017

Copyright (C) 2017 Ulli Vilsmaier, Vera Brandner, Moritz Engbers. This is an open access article distributed under the Creative Commons Attribution License (https://creativecommons.org/licenses/by/4.0/), which permits unrestricted use, distribution, and reproduction in any medium, provided the original work is properly cited.

Available online 22 January 2018 at www.atlas-journal.org, doi: 10.22545/2017/00093

\section{T} ransdisciplinary research can be considered an integrative practice that is grounded in difference. It emerges as in-between space established among societal domains, different ways of knowing, acting and being, and constitutes a new topos in the landscape of societal institutions. We argue that it is through difference that transdisciplinary research spaces are created and elaborate on the characteristics of these in-between spaces. We provide insights into theoretical considerations of the constitution of in-between spaces for transdisciplinary research and show how cultural differences, determined by existing power relations and hegemonies, can be brought into fruition. Our aim is to contribute to theoretical considerations of a concept of research that is not reduced to academic research only but considered a cultural practice of people at stake to better understand and transform situations or phenomena of shared interest.

Keywords: Research topography, Third Space, integration, differentiation, power relations, transformative research.

\section{Introduction}

In academic discourses on fragmentation and divergence, C. P. Snow's Rede Lecture on The Two Cultures, held in 1959, has marked a milestone. Snow criticises the inability of scientists and humanists to communicate with each other "on the plane of their major intellectual concerns", and points to the "gulf of mutual incomprehension" [1] (4). For him, fragmentation and divergence have serious consequences: "It is leading us to interpret the past wrongly, to misjudge the present, and to deny our hopes for the future. It is making it difficult or impossible for us to take good action." [1] (60). Since then, the landscape of knowledge has changed significantly. The hypothesis of two cultures' is out-dated and both fragmentation and attempts to overcome the divides 
have intensified significantly. The number of specialized fields of knowledge is constantly increasing, but at the same time diverse forms of collaborative, boundary-crossing research practices have developed. Interdisciplinary fields of research, institutions and training programs have evolved in diverse thematic fields [2], [3], and transdisciplinary research has been conceptualized, practiced and discussed for nearly five decades (for an overview on different discourse strands see: Osborn [4], Klein [5]). However, interdisciplinary research is still a not mainstream in the academic system [6], [7] and remains an intellectual, cognitive, communicative, and institutional challenge, particularly in the context of practicing broad interdisciplinarity [8] and working in traditional academic institutions [9]. Transdisciplinarity is hardly consolidated and remains a marginal phenomenon so far, and, above all, it is highly contested. This is not surprising for a concept of research that aims at overcoming divides, not only between academic knowledge fields but also between different cultural spheres of societies [10]. It tackles core pillars of modern science [11], [12], [13] and, as a consequence, the privileged position of the scientific method, by undermining separation [14]. However, the call for a mode of research that does not only cross boundaries of disciplines, but also links knowledge production to the transformation of situations, and, as a consequence, entangles epistemic and transformative objectives, is not new. It is as old as the separation of scientific institutions from the 'remaining rest' [14] and has been put forward by many influential authors who have addressed the challenge from different perspectives over the last decades (e.g., Freire [15], Piaget [16], Hall [17], De Certeau [18], Haraway [19], Guattari [20], Rorty 2002 [21] Nicolescu [13]. Important contributions to research embedded in practice and oriented towards societal transformation have been made by Action Research and Participatory Action Research in various fields related to social science and world regions [22]. Ultimately, the presence of a large number of pressing social and environmental challenges of global dimension [23] proves that there is a need for new ways of dealing with them in order to move towards sustainable, healthy, equitable and peaceful futures. When looking at attempts to fight e.g. climate change, biodiversity loss, warfare and the increase of racist behaviour, the current fragmentation and divergence in societal organization turns out to make it "diffi- cult or impossible for us to take good action" - as Snow stated. Fragmentation and divergence are, of course, not only a result of a search of efficiency. They are a product of contentions concerning dominant societal roles and positions and reflect cultural hegemonies. There is a constant need to recall questions that have already been posed years ago in the field of postcolonial studies and with Gayatri Spivak we ask [24]: Who can speak out loudly? Whose voice is heard, whose knowledge accepted? And, as a corollary, where are places for people to speak out, to be heard and to exchange knowledges and experiences with the ultimate aim to change ways of appropriation and belonging to create sustainable conditions?

In this article we elaborate on the constitution of spaces that are created between established institutions, communities and cultures. We emphasize the potential of actively dealing with differences. In order to make use of differences for the constitution of such in-between spaces, we draw on a broader concept of research that acknowledges the complementarity of academic research practices and other ways of knowing, acting and being in responding to a particular situation or phenomenon of concern. We argue that multiple ways of appropriation and belonging can lead to better grasp the complexity of a situation or phenomenon under inquiry, to gain a more profound understanding on how individual and collective transformation can be achieved, and to actually transform the situation through joint research. In a first step we will elaborate more profoundly on the argument for a broader concept of research. We then look at transdisciplinarity through the lens of culturality that brings about the need to face and approach cultural hegemonies between these different ways of knowing, acting and being we consider significant for transformative research. Subsequently, we elaborate on the theoretical framework of in-between spaces that is informed by the responsive logic Bernhard Waldenfels elaborated [25] and Homi Bhabha's concept of Third Space [26], [27], both concepts that rely on a relational understanding of space and imply the possibility to deal with power relations.

This work is based on experiences in experimenting and practicing transdisciplinary research in the fields of sustainable regional and urban development [28], [29] energy regions [30], sustainable phosphorus management [31], participation of young and marginalized citizen in urban policy processes [32], 
sustainable family farming [33] and on going research in establishing an urban food council and a (Bio)DiversityCorridor for sustainable development. In the following we draw conclusions from these experiments by theoretically contextualizing the concept of research that seems appropriate for a critical transdisciplinary research practice that is constituted in (cultural) difference and thereby creating a space for research in-between.

\section{Broadening the Concept of Research}

In his article on ethical-political foundations of interdisciplinarity ${ }^{1}$ Felix Guattari argues for everyone's right to conduct research. To emphasize his argument, he states: "The UN Charter of Human Rights ought to include an article on the right of everyone to research" [20]. Rethinking and reframing the concept of research form part of Guattari's larger project of a generalized ecology that paved the way for an all-embracing renewal of our concept of existence [34], [35]. It introduces a way of thinking from the in-between, a form of relational thinking that is not based on monadic, static identities but rather on diastatic identities that are formed and constantly renewed in relations. In this perspective, entities and identities related to research can no longer be considered exclusive and separated, but must be seen as embedded in a broader context that is constitutive for research. This has been highlighted by science studies (e.g., Latour [14]; Gibbons et al. [11]; Nowotny, Scott \& Gibbons [12] and acknowledged by several authors who contribute to the formation of a new mode of research (e.g., Haire-Joshu \& McBride [36], Jahn, Bergmann \& Keil [37], Nicolescu [38], Hirsch Hadorn et al. [10], Lawrence \& Després [39], Klein et al. [40]. At closer inspection, societal domains, and accordingly, tasks and roles in society, are increasingly getting blurred. Guattari speaks of a "general deterritorialization of old societal territories, ways and customs, traditions, self-regulating representations [...] and the need to balance out "the pole of a universal rationality" by enlarging the horizons of research [20] (132). Thus, rethinking and reframing the concept of research can be considered

\footnotetext{
${ }^{1}$ Orig. Fondements éthico-politiques de l' itnerdisiplinarité, 1992 - The article of the version published in English in 2015 was re-titled Transdisciplinarity must become transversality'.
}

a response to on going societal transformations that are informed by epochal socio-technological changes. It can also be considered a response to the existential socio-ecological crisis we are facing that calls for creating socially (and culturally) robust knowledge [41], [31], i.e. that it takes "ambiguity, complexity, and contradictions [...] as fundamental features of knowledge" into account [31]. With regards to the ecological crisis, Guattari states: "Scientific ecology, applied to the environment, will remain powerless if it is not relayed by new social and political components [...]." [20] (131). Forms of transdisciplinary research seek to respond to this need.

Research at the science - society interface is being developed in a series of academic fields under the label of transdisciplinarity, in particular in sustainability science (e.g., Lang [42]), health science (e.g., Stokols, Hall \& Vogel [43]) and development studies (e.g., Novy \& Howorka [44]), among others. However, we observe that a large community of scholars - in particular those who focus on the future of the earth - stick to a concept that only relies on scientific rationality and according quality criteria and rigor. Responsibilities for transdisciplinary research remain in academic institutions, while 'external partners', 'non-scientific actors' or stakeholders' are invited to participate. These approaches often remain science-centric and are putting scientists into privileged positions in the research process, e.g. as facilitators [45], [46]. Often, the way language is used mirrors a mono-centric research topography by distinguishing between an active (the scientists) and a passive part (the others). Examples are:'to select stakeholders', 'to integrate actors' or 'to empower people'. This is somehow contradicting several proclaimed transdisciplinary research principles that call for balancing power by installing steeringboards [47], [28] or co-leadership [45], [42], [48], and equal footing [49], [50], [51]. And it contradicts the 'co-' of co-design, co-production and co-creation [52]. Furthermore, it indicates that these concepts of transdisciplinarity do not tackle the underlying epistemological and methodological consequences of such a shift in research topographies. The power of decision, the power of interpretation and, above all, the definition of good practice, quality criteria and ethics of research mainly remain with the scientists. Nevertheless, such forms of research have proven to be utile in a large variety of cases [53], [54], [31], [55], [10], [51], [56], [28], [40]. However, these transdis- 
ciplinary research practices are only the beginning of transforming the landscape and reformulating the concept of research, because "transdisciplinarity must become transversality between science, the socius, aesthetics and politics", as Guattari states [20] (134).

When it comes to tackling pressing societal needs, when knowledge and action are needed to fight crime and poverty, unequal development, the destruction of our physical living conditions and those of nonhuman species, to name just a few, analysis and activism, research and decision-making, as well as knowledge production and societal transformation at large can no longer remain separated. A profound transformation of mentalities is needed [20] (131), and accordingly, a profound reflection on our ways of appropriation and belonging, to overcome unequal diversity [57], [58].

We envision transdisciplinary research spaces that rely on different practices, that aim at multiple objectives and connect people that inhabit different cognitive and material landscapes [59]. They may crystallize as new and explicitly labeled practices and thus form a new topos in the landscape of research, or they may evolve in a particular situation in an appropriate way, without becoming firmly established. Needless to say that such deterritorializations and shifts in the landscape of institutions cause resistance. Historically grown entities that are constituted in rules, norms, value systems and a particular position in relation to others are are geared to stability. Thus, it is not surprising that the formation of more or less institutionalized activities that emerge between traditional institutions is contested. A current example is a debate in Germany about transformative research that addresses societal problem fields. Opponents see it as a threat to science and democracy [60], while others highlight its potential as a valuable addition to the academic system [61], [62]. However, formations and transformations occur despite academic debates. We consider a critical transdisciplinary research practice a third way of dealing with pressing challenges that also changes, on a long run, the landscape of institutions - not by rejecting the existing ones, but by complementing them. Where such activities explicitly address knowing, acting and being in a reflexive manner transversality seems to be a promising concept to describe research in-between. It aims at improving understanding and providing explanations through mutual learning [31] that serve and induce the transformation of a concrete situation. In the following, we look at transdisciplinarity through the lens of culturality to elaborate on cultural differences that become evident in transdisciplinary research.

\section{Transdisciplinary Research: Cultural Difference and Practice}

Similar to Snow's understanding of 'disciplines as cultures', several authors have underlined that culture is not only a concept that relates to nations or ethnicity [63], [64], [65]. We consider culture a process containing practices [66] which can be seen as a "set of doings and sayings" [67] (71) that consist of, e.g., of bodily and mental activities, understanding, know-how, emotions, or the use/usage of things [68] (249). According to Hall, "culture is concerned with the production and the exchange of meanings - the 'giving and taking of meaning' - between the members of a society or group" [66] (2). Meanings indicate understandings and prioritizations and thus refer to knowledge, values, or actions. Processes throughout which meaning is produced, exchanged and negotiated are "open and unstable" [69] (26) and they are historically contingent. Cultural practices are determined by historical social and material conditions [70]. This contrasts with an understanding of culture as a static, essentialist entity often associated with notions of cultures as organic, incommensurable, or "clashing" [71].

Culture comes into being by meaningful differentiations between persons, things, or thoughts [72]. However, own cultural practices of production and differentiation of meaning only become apparent in contrast to other cultural practices. We place ourselves in a "productive borderline space" [73] (209) that is characterized by the ambiquity of cultural differences and their transformative potential: "The borderline engagements of cultural difference may as often be consensual as conflictual; they may confound our definitions of tradition and modernity; realign the customary boundaries between the private and the public, high and low; and challenge normative expectations of development and progress." [27] (3). Such liminal spheres are prerequisites for collective processes of thought and action.

Elaborating on the concept of cultural difference, Bhabha opposes a multicultural apprehension of culture based on "cultural diversity" [27] (50) which, in 
his view, is a sort of hegemonic reaction to difference, forcing a consensus based on one's own norms [27]. Universal, hegemonic and normative positions from which cultural and political judgments are made fail to be unraveled [27] (209). For Bhabha, the concept of cultural diversity implies that there are the Ones deciding who is different, who belongs and who does not, who may contact whom, as well as how, by which means, and how long communication may take place. They also define cultural diversity and who fixes the Others in their role of the culturally alien. In this respect, ethic, aesthetic or ethnological categories are established and compared. Bhabha criticizes the existence of the idea of multiculturalism in which various manifestations of difference are being fixed, coexisting statically or at times replacing one another - however failing to affect each other in any profound way. The transformation processes in which people are constantly involved cannot be adequately taken into account by assuming that culture is identifiable by means of empirical, encyclopedically systematized knowledge. On the contrary, such universalistic attempts would merely dissimulate and reproduce ethnocentric values, interests, norms and racisms. Cultural contents and habits would be regarded as given facts. Rigid universal categories contribute, as Bhabha points out, only to a cultural understanding based on traditional, fixed images of the Others [73] (209ff.). His critique of multiculturalism has been echoed by Fox [74] who, among others, argues that cultural incompatibility (e.g. between values, norms, or truths) is a Eurocentric concept that is brought forward to stabilize positions of dominance and power over others.

Bhabha locates the flaw of such liberal traditions in their one-sided definition established from the angle of a hegemonic culture [73] (208). Difference, in that respect, is only perceived as valuable as long as it complies with a certain normative perception. "The concept of cultural difference focuses on the problem of the ambivalence of cultural authority: the attempt to dominate in the name of a cultural supremacy which is itself produced only in the moment of differentiation." [27] (50). With his concept of cultural difference, Bhabha examines the boundaries of preexisting myths of progress and the related supremacy of 'Western' culture. However, cultural differences are often perceived as a hurdle impossible to be overcome, impeding any exchange on the existing wealth of knowledges and practices. But it is these situations of cultural difference that, according to Bhabha, offer the opportunity of perceiving and negotiating social discrepancies and contradictions rather than ignoring them. "The question of cultural difference faces us with a disposition of knowledges or a distribution of practices that exist beside each other, albeit designating a form of social contradiction or antagonism that has to be negotiated rather than sublated." [27] (232). This is an important indication for transdisciplinary research: The better and 'more bravely' differences are allowed to be explored, articulated and negotiated, the broader a horizon for tackling shared tasks becomes. The aim of such processes is not to force consensus, but rather to highlight the problematic of prioritizing consensus by obscuring differences.

Exploring cultural differences and thereby developing cultural practices of differentiation represents a major potential for transdisciplinary research. As Gürses [75] underlines, our own cultural presuppositions and perceptions appear natural until they become possible to reflect in an act of interculturality. To perceive something as different can lead to understanding and challenging the own cultural categories and orders. However, we do not see differences as static, but diastatic [25], emerging in the situation of differentiation. They are gradual, prioritized, and situational [72].

\section{In-between Spaces for Transdisciplinary Research (5400)}

We will now focus on the constitution of space and show how transdisciplinary research spaces are created by elaborating on differences while sharing a joint objective. When we refer to the in-between, we use the concept of space. When we refer to the joint process where differences are explored and worked on and in so doing a mutual understanding emerges, we use the concept of place [76]. We consider them as two sides of a coin that reflect the bidirectional dynamics of differencing and integrating. Thus, space and place are not a dichotomy, but complementary concepts. Together they form a 'space-place' (Orts-Raum) [77]. The theoretical background of the constitution of space through differencing lies in the tradition of relational concepts of space [78]. Instead of essentializing space as a static 
entity, a 'container', space is considered a relational phenomenon that only exists in relations. Through relations and in relations, spaces are constituted and constantly renewed. Accordingly, they are considered as dynamic, temporal and open. However, it makes a difference how relationality is conceptualized. The question is: Are these relations 'naturally given'? Are they constructed from a privileged position? Are they primordially self-constructed or do they come into existence in response to the Other? Instead of assuming that relations are established between different entities that already exist as such, we consider difference as an occurrence, i.e. emerging in differentiation. In this perspective, space is a diastatic phenomenon [25]. Relationality, that does not rely on origins, and, accordingly, antecedently existing independent entities are denied. What relates has only come into being within a relation. Thus, what appears as discrete - in our context: disciplines, societal domains, cultures, communities - is entangled and complementary. If this entanglement is addressed explicitly in researching collaboration, inbetween spaces can emerge that serve a critical and culturally sensitive transdisciplinarity. Differences create a research space in which place is constituted by a web of meanings and relations. "To that end we should remember" - Homi Bhabha states - "that it is the inter' - the cutting edge of translation and negotiation, the in-between space - that carries the burden of the meaning of culture." [27] (56).

Bhabha takes a closer look at the in-between, based on his anti-essentialist conceptualization of culture that focuses on the articulation of cultural differences, as shown above. He considers such inbetween spaces a "terrain for elaborating strategies of selfhood - singular or communal - that initiate new signs of identity, and innovative sites of collaboration, and contestation, in the act of defining the idea of the society itself." [27] (2). He refers to such spaces as Third Spaces. Third Spaces are culturally hybrid spheres of multiple, but shared identities that are constantly developed and renewed between cultures through dialogue. They provide "the discursive conditions of enunciation that ensure that the meaning and symbols of culture have no primordial unity or fixity; that even the same signs can be appropriated, translated, rehistoricized and read anew." [27] (55). Concerning the constitution of Third Spaces, he highlights the need to "think beyond narratives of originary and initial subjectivi- ties" [27] (2). Theoretically (and politically) this is in line with Waldenfels conceptualization of responsivity. He considers the occurrence as primordial to the emergence of a something that comes into appearance in the landscape of meaning.

A Third Space can be opened as transdisciplinary research space, holding the possibility of going beyond everyday experiences, livelihoods and research practices. In Bhabha's view, this creates a space of articulation in which the own, the uncertain and the differences can perpetually be fathomed, interpreted and negotiated. Existing structures, power relations and dependencies can be suspended - at least for a situational episode - when discrepancies are articulated and thereby made tangible. There is a need to explore, name and negotiate the differences. The in-between space, the gap that occurs as a result of an experience of difference, facilitates the renegotiation of identity, of creating new meaning for things, and elicits a process of constant transformation that we are all involved in. "And by exploring this Third Space, we may elude the politics of polarity and emerge as the others of ourselves." [27] (56). In the Third Space as a transgressive space [79] (235), the concept of a separating line between and within social spaces loses its one-dimensional, exclusive character [27] (5). It represents a concept of space with inherent dynamics and an understanding that enables the un-fixing of established positions and images [79] (53f.). Boundaries that represent the outer limits of a certain culture, political stance or epistemology move into the center of a Third Space perception. "This interstitial passage between fixed identifications opens up the possibility of a cultural hybridity that entertains difference without an assumed or imposed hierarchy [...]." [27] (5). Hereby, the potential of differencing - to divide and unite at the same time - becomes obvious.

\section{Concluding Remarks}

The practise of differentiation in transdisciplinary research is not an analytical task. No view from outside, not the best set of data, nor a "stakeholder mapping' can achieve what emerges "in vivo", as Basarab Nicolescu states [80], when differences become apparent through differentiation. The occurrence of difference is irreducibly complex when the Own transforms in the formation of the Other. In order to bring differences into fruition, it is neces- 
sary that all involved become aware of the need to explicitly address them. By perceiving and increasingly becoming aware of the Own and the Others' subjugation to a certain habitus, rationale, value systems and norms, as well as the preconditions of individual thoughts and actions can be examined and questioned. This is already a shared research task that creates conditions for joint thinking and acting and at the same time mutual understanding on the different positions and perspectives. Experiencing difference becomes a reflexive process in which a particular situatedness is not merely an obstacle, but a generative principle that produces forms of social practice [68], one that constitutes the in-between.

Being determined by cultural differences, transdisciplinary research has to be considered a cultural practice in which a variety of meanings is produced, exchanged, and negotiated. The overall potential of seeing transdisciplinary research as an intercultural phenomenon is to understand the "constitution of differences" [82] (13). It leads to a reconfiguration of existing practices and the formation of new ways of research. When we explore and work on cultural differences, we can unfold a potential that is threefold: Firstly, it allows to critically (self-)reflect on often implicit premises of our thinking and working styles, norms and foundations of knowledge, and thus, on underlying social and material conditions. This can support openness as the 'unknowns' of one's own position become apparent and can thus be explained, negotiated, and defended. Secondly, dominant cultural regimes can be questioned, and positions that usually remain neglected, but might reveal a complementary perspective on the subject matter can be recognized. In consequence, a more integrated and comprehensive understanding of the subject of research can be achieved. Thirdly, collective practices can be developed that are more appropriate to understand and transform a particular situation or phenomenon of concern. As they are informed by a plurality of ways of knowing, being, acting and reflecting, they respond to complexity and intertwined conditions by being complex and intertwined themselves. However, research in the in-between, as outlined in this article, also has its inconveniences. Firstly, what has been described so far as practice of differentiation is very time-consuming. A certain degree of confidence and a language of mutual comprehension have to develop among the persons involved in order to prepare for joint re- search on a shared issue. Secondly, analyzing one's own positions against the background of the Other is also not an analytical task. It requires interest, openness, empathy and willingness to learn. And last, but equally importantly, it calls for sharing power, which goes along with a loss of influence and control.

In his introduction to the essay collection 'Eine Kultur ohne Zentrum', Richard Rorty suggests that the best practice of dealing with cultural hegemonies would be one that constantly shifts its focus depending on which group or individual just made an inspiring, original or useful contribution [21] (5). This might become a guiding principle for transdisciplinary research, a principle that acknowledges, respects and encourages differences and that does without ultimate authorities.

Author Contributions: Paper was written collaboratively by the authors.

Funding: This research received no external funding.

Conflicts of Interest: The authors declare no conflict of interest.

\section{References}

[1] Snow, Charles Percy (1988) [1964]. The two cultures and a second look. Cambridge: Cambridge University Press.

[2] Frodeman, R., J.T. Klein \& Mitcham, C. (Eds.) (2010). The Oxford Handbook of Interdisciplinarity. New York (et al.): Oxford University Press.

[3] Weingart, P. \& Stehr, N. (Eds.) (2000). Practising Interdisciplinarity. Toronto (et al.): University of Toronto Press.

[4] Osborne, P. (2015). Problematizing Disciplinarity, Transdisciplinarity Problematics. Theory, Culture \& Society, 0, 1-33.

[5] Klein, J. T. (2014). Discourses of transdisciplinarity: Looking back to the future. Futures, 63: 68-74.

[6] Lawrence, R. J. (2016). Interdisciplinary Science: A coming of Age? The New York Academy of Sciences. New York Academy of Sciences Magazine, Spring, 3rd May 2016. Document in http://www.akademien-schweiz.ch/td-net/tdInfo/Publications.html? $\mathrm{a}=0111111$. Retrieved in August 2016.

[7] Ledford, H. (2015). How to solve the world's biggest problems. Nature, 525: 308-311. 
[8] Klein, J. T. (2010). A taxonomy of interdisciplinarity. In: Frodeman, R., Klein, J. T., Mitcham, C. (Eds.): The Oxford handbook of interdisciplinarity. Oxford (et al.) Oxford University Press, 15-30.

[9] Roy, E. D., Morzillo, A. T., Seijo, F., Reddy S. M. W., R. J. M., Milder, J. C., Kuemmerle, T. \& Martin, S. L. (2013): The elusive pursuit of interdisciplinarity at the human-environment interface. BioScience, 63(9): 745-753.

[10] Hirsch Hadorn, G.; Bradley, D.; Pohl, C., Rist, S.; Wiesmann, U. (2006). Implications of transdisciplinarity for sustainability research. Ecological Economics, 60(1): 119-128.

[11] Gibbons, M., Limoges, C., Nowotny, H., Schwartzman, S., Scott, P. \& Trow, M. (1994). The new production of knowledge: The dynamics of science and research in contemporary societies. London (et al.): SAGE.

[12] Nowotny, H.; Scott, P. \& Gibbons, M. (2001). Rethinking science: Knowledge and the public in an age of uncertainty. Cambridge: Polity Press.

[13] Nicolescu, B. (2002). Manifesto of Transdisciplinarity. Albany: State University of New York Press.

[14] Latour, B. (1999). Pandora's hope: Essays on the reality of science studies. Cambridge (et al.): Harvard University Press.

[15] Freire, Paulo (1996). Pedagogy of the Oppressed. London (et al.): Penguin Books.

[16] Piaget, J. (1972). Psychology and epistemology: Towards a theory of knowledge. London: Allen Lane.

[17] Hall, S. (1980). Cultural studies: Two paradigms. Media, Culture and Society, 2(1): 57-72.

[18] De Certeau, M. (1984). The practice of everyday life. Berkeley (et al.): University of California Press.

[19] Haraway, D. (1988). Situated knowledges: The science question in feminism and the privilege of partial perspective. Feminist Studies, 14(3): 575-599.

[20] Guattari, F. (2015) [1992]. Transdisciplinarity must become transversality. Theory, Culture; Society, 32(5-6): 131-137.

[21] Rorty, R. (2002). Eine Kultur ohne Zentrum. Vier philosophische Essays. Stuttgart: Reclam.

[22] Reason, P. \& Bradbury, H. (Eds.) (2001). Handbook of Action Research. Participative Inquiry and Practice. London et al.: Sage Publications.

[23] Reid, W. V., Chen, D., Goldfarb, L., Hackmann, H., Lee, Y. T., Mokhele, K., Ostrom, E., Raivio, K., Rockström, J.; Schellnhuber, H. J. \& Whyte, A. (2010). Earth system science for global sustainability: Grand challenges. Science, 330: 916-917.
[24] Spivak, Gayatri Chakravorty (2007). Can the Subaltern Speak? Postkolonialität und subalterne Artikulation. Wien: Turia und Kant.

[25] Waldenfels, B. (2011). Phenomenology of the alien: Basic concepts. Evanston: Northwestern University Press.

[26] Bhabha, H. K. (1994). The location of culture. London, New York: Routledge.

[27] Bhabha, H. K. (2004). The Location of Culture. New York: Routledge.

[28] Muhar, A., Vilsmaier, U., Glanzer, M. \& Freyer, B. (2006). Initiating transdisciplinarity in academic case study teaching: Experiences from a regional development project in Salzburg, Austria. International Journal of Sustainability in Higher Education, 7: 293-308.

[29] Vilsmaier, U. (2008). Crossing borders: Transdisciplinary approaches in regional development. -In: Geographica Timisiensis 17/1-2, 33-43.

[30] Hecher, M., U. Vilsmaier, R. Akhavan \& Binder, C. R. (2016). Combining energy flow analysis with agent and policy analysis to examine the transition of energy regions: the case study of the koEnergieland in Austria. Ecological Economics, 121: 4053.

[31] Vilsmaier, U., Engbers, M., Luthardt, P., MaasDeipenbrock, R. M.; Wunderlich, S. \& Scholz, R. W. (2015). Case-based mutual learning sessions: Knowledge integration and transfer in transdisciplinary processes. Sustainability Science, 10: 563-580.

[32] Vilsmaier, U. \& Lang, D. J. (2015). Making a difference by marking the difference: constituting inbetween spaces for sustainability learning. -In: Current Opinion in Environmental Sustainability, 16, 51-55.

[33] Ortiz, W., U. Vilsmaier \& Acevedo Osorio, Á. (2017). The diffusion of sustainable family farming practices in Colombia An emerging sociotechnical niche? In: Sustainability Science (DOI 10.1007/s11625-0170493-6).

[34] Guattari, F. (1989). The three ecologies. New Formations, 8: 131-147.

[35] Hörl, E. (2016). Die Ökologisierung des Denkens. Zeitschrift für Medienwissenschaft, 14: 33-45.

[36] Haire-Joshu, D. \& McBride, T. D. (2013). Transdisciplinary public health: Research, methods, and practice. San Francisco: Jossey-Bass.

[37] Jahn, T., Bergmann, M. \& Keil, F. (2012). Transdisciplinarity: Between mainstreaming and marginalization. Ecological Economics, 79: 1-10.

[38] Nicolescu, B. (Ed.) (2008). Transdisciplinarity: Theory and practice. Cresskill: Hampton Press. 
[39] Lawrence, R. \& Després, C. (2004). Futures of Transdisciplinarity. Futures, 36(4): 397-405.

[40] Klein, J. T., Grossenbacher-Mansuy, W., Häberli, R.; Bill, A., Scholz, R. and Welti, M.Klein, J. T.; Grossenbacher-Mansuy, W.; Häberli, R.; Bill, A.; Scholz, R. \& Welti, M. (Eds.) (2001). Transdisciplinarity: Joint problem solving among science, technology, and society: An effective way for managing complexity. Basel (et al.): Birkhäuser.

[41] Scholz, R. W. (2011). Environmental literacy in science and society: From knowledge to decisions. Cambridge, New York: Cambridge University Press.

[42] Lang, D., Wiek, A., Bergmann, M., Stauffacher, M., Martens, P., Moll, P., Swilling, M. \& Thomas, C. (2012). Transdisciplinary research in sustainability science: Practice, principles, and challenges. Sustainability Science, 7(SUPPL. 1): 25-43.

[43] Stokols, D., Hall, K. \& Vogel, A. (2013). Transdisciplinary public health: Definitions, core characteristics, and strategies for success. In: Haire-Joshu, D.; McBride, T. D. (Eds.): Transdisciplinary public health: Research, methods, and practice. San Francisco: Jossey-Bass, 3-30.

[44] Novy, A. \& Howorka S. (2014). Transdisziplinarität und Wissensallianzen. In: Dannecker, P.; Englert, B. (Eds.): Qualitative Methoden in der Entwicklungsforschung. Wien: Mandelbaum.

[45] Scholz, R. W. \& Steiner, G. (2015). The real type and ideal type of transdisciplinary processes: Part I - Theoretical foundations. Sustainability Science, 10: 527-544.

[46] Pohl, C.; Rist, S.; Zimmermann, A., Fry, P., Gurung, G. S., Schneider, F., Speranza, C. I., Kiteme, B., Boillat, S., Serrano, E., Hadorn, G. H. \& Wiesmann, U. (2010). Researchers' roles in knowledge co-production: Experience from sustainability research in Kenya, Switzerland, Bolivia and Nepal. Science and Public Policy, 37(4): 267-281.

[47] Scholz, R. W.; Spoerri, A. \& Lang, D. J. (2009). Problem structuring for transitions: The case of Swiss waste management. Futures, 41: 171-181.

[48] Rosendahl, J., Zanella, M. A., Rist, S. \& Weigelt, J. (2015). Scientists situated knowledge: Strong objectivity in transdisciplinarity. Sustainability Science, 65: $17-27$.

[49] Scholz, R. W. \& Steiner, G. (2015a). Transdisciplinarity at the crossroad. Sustainability Science, 10: 521-526.

[50] Mobjörk, M. (2010). Consulting versus participatory transdisciplinarity: A refined classification of transdisciplinary research. Futures, 42: 866-873.

[51] Stauffacher, M.; Flüler, T.; Krütli, P. \& Scholz, R. (2008). Analytic and dynamic approach to collabora- tion: A transdisciplinary case study on sustainable landscape development in a Swiss prealpine region. Systemic Practice and Action Research, 21 (6): 409422.

[52] Mauser, W., Keppler, G., Rice, M., Schmalzbauer, B. S., Hackmann, H., Leemans, R. \& Moore, H. (2013). Transdisciplinary global change research: the co-creation of knowledge for sustainability. Current Oppinion in Environmental Sustainability, 5(3-4): 420-431.

[53] Berger-González, M., Stauffacher, M., Zinsstag, J., Edwards, P. \& Krütli, P. (2016). Transdisciplinary research on cancer-healing systems between biomedicine and the Maya of Guatemala: A tool for reciprocal reflexivity in a multi-epistemological setting. Qualitative Health Research, 26: 77-91.

[54] Miah, J. H.; Griffiths, A., McNeill, R., Poonaji, I., Martin, R., Morse, S., Yang, A. \& Sadhukhan, J. (2015). A small-scale transdisciplinary process to maximising the energy efficiency of food factories: Insights and recommendations form the development of a novel heat integration framework. Sustainability Science, 10: 621-637.

[55] Bergmann, M., Jahn, T., Knobloch, T., Krohn, W., Pohl, C. \& Schramm, E. (2012). Methods for transdisciplinary research: A primer for practice. Frankfurt (Main) (et al.): Campus.

[56] Scholz, R. W. \& Stauffacher, M. (2007). Managing transition in clusters: Area development negotiations as a tool for sustaining traditional industries in a Swiss prealpine region, Environment and Planning A, 39: 2518-2539.

[57] Novy, A.; Habersack, S. \& Schaller, B. (2013). Innovative forms of knowledge production: Transdisciplinarity and knowledge alliances. In: Moulaert, F., MacCallum, D., Mehmood, A., Hamdouch, A. (Eds.): The international handbook on social innovation. Cheltenham, Northampton: Edward Elgar Publishing, 430-441.

[58] Novy, A. (2012). "Unequal diversity" as a knowledge alliance: An encounter of Paulo Freire's dialogical approach and transdisciplinarity. Multicultural Education \& Technology Journal, 6(3): 148.

[59] Felt, U. (2009): Introduction: Knowing and living in academic research. In: Felt, U. (Ed.). Knowing and living in academic research: Convergence and heterogeneity in research cultures in the European context. Prague: Institute of Sociology of the Academy of Science of the Czech Republic, 17-40.

[60] Strohschneider, P. (2014). Zur Politik der Transformativen Wissenschaft. In: Brodocz, A.; Herrmann, D.; Schmidt, R.; Schulz, D.; Schulze Wessel, J. (Ed.): Die Verfassung des Politischen. Wiesbaden: Springer VS, 175-192. 
[61] Grunwald, A. (2015). Transformative Wissenschaft: Eine neue Ordnung im Wissenschaftsbetrieb? GAIA, 24(1): 17-20.

[62] Schneidewind, U. (2015). Transformative Wissenschaft: Motor für gute Wissenschaft und lebendige Demokratie. GAIA, 24(2): 88-91.Senghaas, D. (1998): Zivilisierung wider Willen. Frankfurt (Main): Suhrkamp.

[63] Göller, T. (2000). Kulturverstehen: Grundprobleme einer epistemologischen Theorie der Kulturalität und kulturellen Erkenntnis. Würzburg: Königshausen \& Neumann.

[64] Hansen, K. P. (2011). Kultur und Kulturwissenschaft. 4th ed., Tübingen (et al.): Francke.

[65] Senghaas (1998). Zivilisierung wider Willen. Frankfurt a.M.: Suhrkamp.

[66] Hall, S. (1997): Introduction. In: Hall, S. (Ed.). Representation: Cultural representations and signifying practices. London (et al.): SAGE, 1-11.

[67] Schatzki, T. R. (2002). The site of the social: A philosophical account of the constitution of social life and change. University Park: The Pennsylvania State University Press.

[68] Reckwitz, A. (2002). Toward a theory of social practices: A development in culturalist theorizing. European Journal of Social Theory, 5(2): 243-263.

[69] Wimmer, A. (2002). Compromise and closure: A theory of social dynamics. In: Wimmer, A. (Ed.): Nationalist exclusion and ethnic conflicts: Shadows of modernity. Cambridge: Cambridge University Press, 19-41.

[70] Lindner, R. (2003). Konjunktur und Krise des Kulturkonzepts. In: Musner, L.; Wunberg, G. (Eds.): Kulturwissenschaften: Forschung, Praxis, Positionen. Freiburg im Breisgau: Rombach, 75-95.

[71] Huntington, S. (2002). The clash of civilizations and the remaking of world order. London (et al.): Free Press.

[72] Hirschauer, S. (2014). Un/doing Differences: Die Kontingenz sozialer Zugehrigkeiten. Zeitschrift für Soziologie, 43(3): 170-191.

[73] Rutherford, J. (1990). The third space: Interview with Homi Bhabha. In: Rutherford, J. (Ed.): Identity: Community, culture, difference. London: Lawrence and Wishart, 207-221.

[74] Fox, C. (1997): The authenticity of intercultural communication. International Journal of Intercultural Relations, 21(1): 85-103.

[75] Gürses, H. (2010). Kultur lernen: auf der Suche nach dem eigenen Ebenbild? - Philosophische und politiktheoretische Überlegungen zur Kulturalität. SWS-Rundschau, 3: 278-296.
[76] Vilsmaier, U. (2009). ÜberRäumlichkeit. Ein Beitrag zur anthropologischen Konstitution von Raum. (=Doctoral Thesis at the Faculty of Natural Sciences of the University of Salzburg). -Salzburg.

[77] Waldenfels, B. (2009). Ortsverschiebungen, Zeitverschiebungen. Modi leibhafter Erfahrung. Frankfurt (Main): Suhrkamp.

[78] Günzel, (2007). Raum - Topographie - Topologie. In: Günzel, S. (Ed.): Topologie. Zur Raumbeschreibung in den Kultur- und Medienwissenschaften. Bielefeld: Transcript, 13-32.

[79] Brandes (2010). Fotographie und "Identität". Visuelle Repräsentationspolitiken in künstlerischen Arbeiten der 1980er und 1990er Jahre. Bielefeld: Transkript.

[80] Nicolescu, B. (2008a). In vitro and in vivo knowledge: Methodology of transdisciplinarity. In: Nicolescu, B. (Ed.) (2008). Transdisciplinarity: Theory and practice. Cresskill: Hampton Press.

[81] Rose, G. (1997). Situating knowledges: Positionality, reflexivities and other tactics. Progress in Human Geography, 21(3): 305-320.

\section{About the Authors}

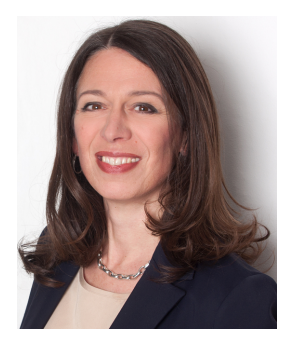

Ulli Vilsmaier is working in the field of inter- and transdisciplinarity and currently holds an adjunct professorship position for Transdisciplinary Methods at the Methodology Center of Leuphana University Lüneburg, Germany. Her research and teaching focus is on epistemological and methodological foundations, methods for inter- and transdisciplinary research, and the constitution of space. She is accompanying inter- and transdisciplinary research teams, is involved in a series of projects related to the development of concept-, image- and artifact based methods for boundary work, and sustainability. Ulli Vilsmaier was trained as a Geographer at Salzburg University and is strongly influenced by Paulo Freires pedagogy and the responsive logic developed by Bernhard Waldenfels.

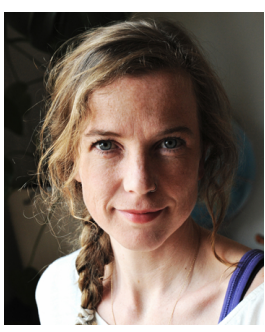


Vera Brandner is working as researcher, photographer and activist and is currently holding a postdoctoral position at the Institute for Sociology at the University of Innsbruck. Since 2003, she is the conceptual director of the intercultural art association ipsum (www.ipsum.at) and has been designing and implementing projects in the field of intercultural communication and conflict work in Angola, Pakistan, Afghanistan, Israel, Palestine, Uganda, Austria and Germany. Her main research and teaching interests are cultural difference and educational disparities, inter- and transdisciplinary methods and methodologies, participatory photographic research.

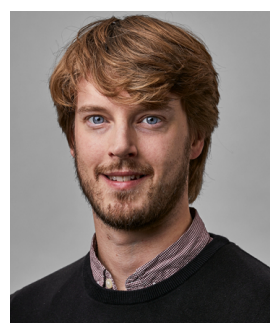

Moritz Engbers is a research associate in the project "Leverage Points for Sustainability Transformation" at Leuphana University Lüneburg in Germany. His focus is on the design and implementation of a transdisciplinary case study with scientists, artists, regional representatives, and the general public. In his doctoral thesis he conducted research on culture and difference in transdisciplinary sustainability research. As a researcher, facilitator and geographer, Moritz Engbers is interested in cultural difference, methods and methodologies of inter- and transdisciplinary research, mutual learning, and socio-ecological transformation. 